\title{
Chapter 3: \\ Restricted Experientiality
}

Experientiality plays less of a role if the visitor is primarily a passive observer. To create experientiality, a museum must allow the visitor to act as mediating consciousness within the semiotic space of the museum. Experientiality is especially restricted when visitors see all of a museum's individual objects and voices as part of a greater master narrative or argumentative framework, whether provided by the museum's main mission statement or constantly reinforced through specific exhibition techniques. As discussed above, we can differentiate between restricted experientiality (when museums do not leave visitors room to mediate between museum space and history), primary experientiality (where visitors are placed in a position to experience collective perspectives from the past; there is a mimetic relationship between museum simulations and past experiences), and secondary experientiality (in which visitors can have structural experiences of the past that do not have predecessors in an actual historical world, but instead simulate historical structures). Most exhibitions have components of all three forms of experientiality.

Visitors are doubtless deeply impacted by their previous knowledge, and there is no easy way - barring a substantial, empirical visitor survey - to speculate about what knowledge they have upon entering an exhibition about the Second World War. John H. Falk (2009, 58-65, 81-82) has argued that exhibitions often primarily reinforce the visitor's pre-existing knowledge, rather than completely reshaping their views. If a museum on the Second World War puts forward a very clear message about national identity, it follows that such a strategy uses existing master narratives and myths to reinforce an existing cultural memory among its main (most often national) audience. In this way, the museum takes on the task of forming national identity via the promotion of cultural memory. This task can be accompanied by strong commemorative functions, with regard to either heroes or victims, and can intersect with different historical truthclaims. These can function as historiographical truth-claims, authenticated through historical research. They can also be established through the use of emotional and aesthetic representative techniques that give the visitor the impression of factuality.

This chapter demonstrates how three Second World War museums and exhibitions restrict their potential experientiality through the establishment of master narratives and the reinforcement of existing memory patterns. The Canadian War Museum - a hybrid of a history museum, aiming for historical objectivity and a commemorative memorial museum - establishes a strong linear national

○ OpenAccess. ( 2020 Stephan Jaeger, published by De Gruyter. (cc) BY-NC-ND This work is licensed under the Creative Commons Attribution-NonCommercial-NoDerivatives 4.0 License. 
master narrative that builds Canadian national identity through war. The Warsaw Rising Museum, a hybrid of a memorial, narrative history, and experiential museum, establishes a factual narrative of a specific historical event and its significance for national collective memory; the museum reinforces this by using emotional means to steer the visitor toward its represented version of historical truth. On the one hand, the Imperial War Museum in London, particularly in its permanent exhibition A Family in Wartime (that closed in January 2019), simulated the collective British experience of war on the home front; on the other hand, visitors had no opportunity to actively use their consciousness to mediate and diversify the collective experience that it presents. Consequently, the exhibition primarily reaffirmed existing cultural memory and restricted experientiality by enabling the visitor to empathize with a historical collective, instead of allowing for the development of primary experientiality.

\subsection{The Canadian War Museum in Ottawa}

The Canadian War Museum (CWM) in Ottawa re-opened in a new building designed by Raymond Moriyama on May 8, 2005. The design of the bunker-like building is based on the theme of regeneration: "By fully integrating this theme into the building and landscape architecture through energy-efficient features, the use of recycled materials and a green roof, the museum recognizes the harsh reality of war, yet offers hope that, like the regenerating landscape, Canadians will inherit a future free from conflict."1 Although the CWM was officially founded in 1942, the roots of this national, publicly funded museum can be traced back to a national collection of military artifacts that have been in the possession of the Canadian federal government since 1880. Today the CWM is part of the Canadian Museum of History Corporation and is attended by about 500.000 visitors a year (Canadian War Museum 2016). It is located on LeBreton Flats, west of Parliament Hill. The Peace Tower of the central parliament building forms an axis with the museum, indicating the interwovenness of memorial culture within the city of Ottawa and the CWM (see also Greenberg 2008). In the years before its opening, the proposed museum generated a number of public controversies, especially regarding the role of the Holocaust in the museum and the depiction of the Air War in Europe. ${ }^{2}$

1 https://www.warmuseum.ca/about/building-features/\#tabs, accessed 13 October 2019. See also Moriyama 2006.

2 See chapters 7 and 8 where these debates will be discussed in detail. 
In its 2005 permanent exhibition, ${ }^{3}$ the CWM presents the Second World War as a national Canadian endeavor: "The Museum's exhibition galleries and public programs have been designed to emphasize the human experience of war. The Canadian Experience Galleries present the military history of Canada from earliest times to present day and Canada's history of honoring and remembrance. Each gallery highlights defining moments in Canada's military history and the ways in which past events have shaped the nation" (Canadian War Museum 2019). ${ }^{4}$ The museum functions as a hybrid of military history and memorial museum, which - in its twenty-first-century version - is strongly shaped by its narrative structure. As a military history museum, it aims for historical objectivity by choosing a partially distant, documentary approach in its depiction of themes, images, and artifacts. As a memorial museum, the CWM mainly holds the potential for primary experientiality by simulating the collective perspectives of Canadian soldiers and, to a lesser extent, Canadians on the home front. The master narrative toward national unity "forged out of diversity" (Rukszto 2008, 751), however, reduces this experientiality. It also steers the Second World War gallery away from creating empathy with Canadian collectives and instead toward causally linking the war with nationhood and national identity. ${ }^{5}$ There is constant tension between the goal of historical objectivity and the memory narrative promoting national identity (Ives 2012, 120).

In accordance with its mandate, the CWM exclusively exhibits the war from a Canadian perspective, progressing chronologically in the four "Canadian Experience Galleries," comprising 5,028 square meters. ${ }^{6}$ The museum developed the concept of four intertwined principles, each one of which becomes a leading principle in one of the four galleries. Gallery 1 is shaped by geography (conflicts

3 For a full genesis of the new museum, the debates about its location, and the public debates around the museum see Hillmer 2010.

4 https://www.warmuseum.ca/about/about-the-museum/\#tabs, accessed 13 October 2019.

5 Rukszto $(2008,749)$ emphasizes the didactic and often moralizing style of the linear master narrative of the exhibition: "Its pedagogy is much more teacherly, offering lessons that are meant to connect the visitor to the past and the future, and to others as members of a national community. This strategic pedagogy is 'moralizing': the images of destruction and death, sacrifice and survival, rebirth and democracy provide lessons in the past so that the future will not be the same, to ensure that it will be better."

6 See the construction fast fact-sheet (Canadian War Museum 2015). The four galleries are supplemented by a Memory Hall that functions as a symbolic chapel to commemorate the fallen, the Regeneration Hall, the Royal Canadian Legion Hall of Honour, displaying the ways of heroically commemorating the deeds of soldiers in all Canadian wars, and the LeBreton Gallery displaying large military equipment. Additionally, the CWM features corridors with a collection of large Canadian war paintings and space for special exhibitions. 
around rivers, streams, water); ${ }^{7}$ gallery 2 by brutality (the dreadfulness of war); gallery 3 on the Second World War by politics (a national and 'almost' just war); and the post-war gallery that ends in the present is shaped by survival (the nuclear war in the public eye). ${ }^{8}$ The key concepts are also introduced to the visitor through conceptual phrases on the walls of the opening rotunda preceding the four galleries. Among these are the conceptual pairs of fear and courage, sacrifice and survival, and brutality and humanity. The beginning of the first gallery defines war as "organized, armed conflict," and states that: "Virtually every human society, past and present, makes war." The introductory wall panel expresses that "war has shaped Canada and Canadians for at least 5,000 years," before showing the material roots of war on the geographical territory that constitutes Canada today. In this way, war becomes an anthropological identifier for the emergence of Canadian society and civilization.

At the end of the second gallery "For Crown and Country: The South African and First World Wars, 1885-1931," the visitor reads and hears, on the one hand, about the heavy losses sustained and Canadian grief. On the other hand, the CWM presents a large panel with an image of the Peace Tower of the Canadian Parliament building entitled "An Unfinished Country." The panel text reads: "Canada emerged from the war proud and victorious, and with a new standing in the world. It was also a grieving and divided country." The motive of independence - the Canadians signing the Treaty of Versailles independently from Britain in 1919 and gaining formal independence by 1931 - frames this national master narrative. Implicitly, war is the CWM's medium for Canadian national identity, sovereignty, and the collective feeling of becoming a nation (see also Ives 2012, 124). In this master narrative, the Second World War is necessary for the completion of the Canadian nation. Consequently, the third gallery of the museum entitled "Forged in Fire: The Second World War, 1931-1945"9 is introduced

7 For a detailed analysis of the memory strategies used to express the development toward national identity in this gallery see Ives 2012, 126-131. Ives argues that the idea of the national narrative out of conflict of is presented "through the eyes of the dominant English-speaking majority" (131): "If war is ultimately about victory and defeat, the War Museum is about how in Canada the winners have tried to integrate the losers, entwining them as one strand in a national narrative, swallowing them whole and then asking them to reflect on their place in a wider story" (126).

8 I am grateful to Dean Oliver, current Director Research at the Canadian Museum of History and former Director of Research and Exhibitions for explaining the original concept of the CWM to me, in a meeting on June 3, 2015. However, all analysis of the exhibition concept is my own.

9 I am grateful to Jeff Noakes, current curator for the Second World War gallery for his detailed explanation on the curatorial decisions in a personal guided tour on 29 May 2015. 


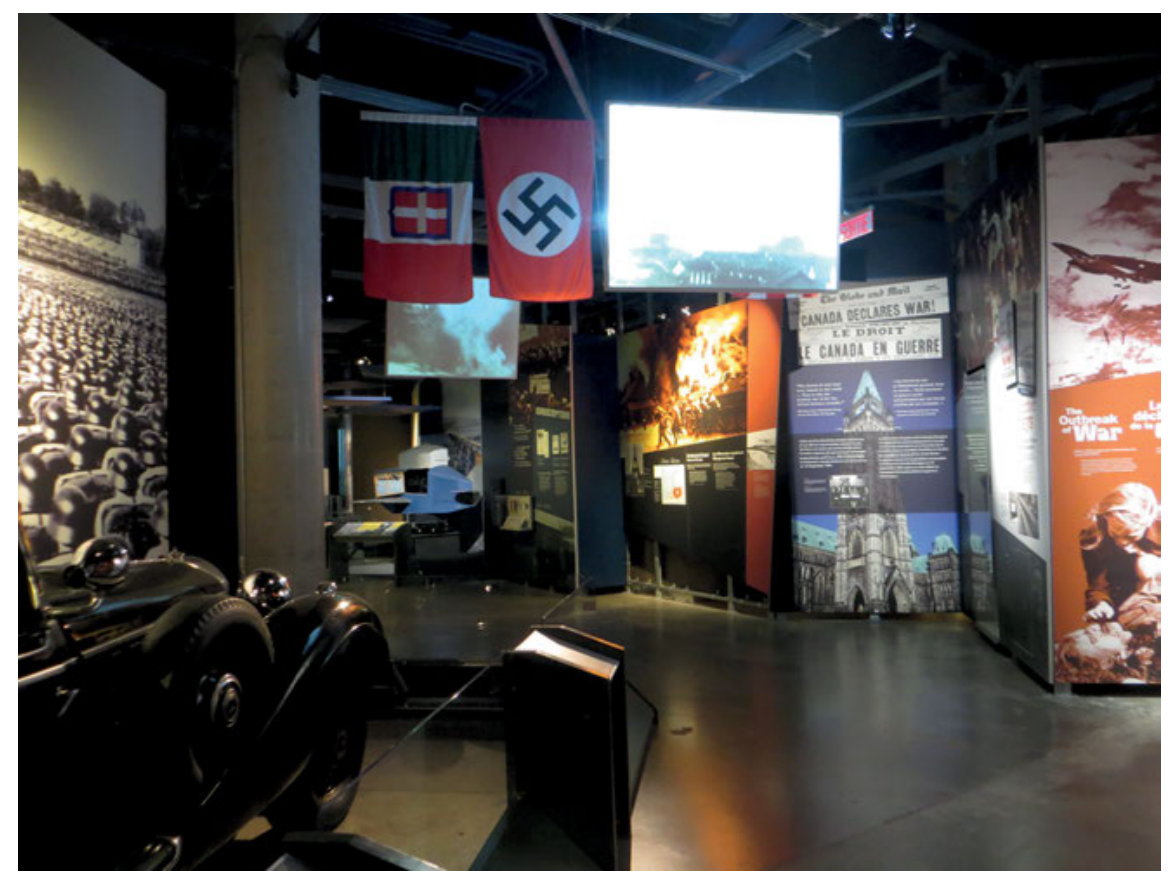

Fig. 4 Opening section of gallery "Forged in Fire: The Second World War, 1931-1945." Permanent exhibition. Canadian War Museum, Ottawa (Photo: Author, 2015, courtesy of Canadian War Museum).

through a synopsis sentence: “Canada's fight against dictatorships overseas transformed the country and its place in the world." In the last section, visitors encounter a large panel entitled "A Nation Transformed," picking up on the theme of the "unfinished" nation from the second gallery. The panel text reads: "The Second World War was a massive national enterprise, and Canada emerged from the conflict as an economic and international power - united, self-confident, prosperous, and determined to make a difference in the world." 10 The gallery develops chronologically. At the beginning, the exhibition presents the political situation in Canada and marks the emergence of dictatorships in Germany, Italy, and Japan through flags and video footage installations hanging from the ceiling (see fig. 4). The artifact of a Mercedes Benz limousine,

10 This allows Canadian peacekeeping efforts to be highlighted in the fourth gallery "A Violent Peace: The Cold War, Peacekeeping, and Recent Conflicts - 1945 to the Present.” 
which Hitler used as parade car, entitled "Hitler's Car: A Symbol of Evil"11 serves as focal point for the visitor and emotionally prepares them for the moral need for a just war (see also Matthews 2013, 279). After this, the exhibition touches on air force training in Canada, threats to Canada by sea, and home front efforts during the war, before following Canadian troops through various wartime engagements: these include Dieppe, the Air War in Europe, the Italian Campaign, D-Day, the liberation of the Netherlands, and the last battles on Germany territory. It closes with the discovery of the concentration camps and homecoming after the war. A minor strand highlights the Canadian involvement in the Pacific, the loss in the Battle of Hong Kong in December 1941, and the history and liberation of Canadian prisoners of war from Japanese internment camps.

The national master narrative of the gallery imparts the message that Canada became an independent and confident nation through war, with the Second World War marking the completion of the process of national independence on the international stage. Consequently, the CWM reflects on the Second World War by exclusively presenting Canadian issues and a Canadian collective perspective. This highlights the political situation in Canada, the home front, and the collective gaze of the Canadian soldiers in a manner similar to the American National World War Two Museum in New Orleans. ${ }^{12}$ Unlike the New Orleans WWII Museum, the CWM only briefly addresses other wartime events. At the beginning, the visitor encounters a brief info panel on the German attack on Poland to mark the beginning of the war, supported by an iconic image taken during the Warsaw Siege. ${ }^{13}$ In the second section "The Canadian Response," a similar panel briefly describes the Blitzkrieg in a short paragraph; later on in the same section, Dunkirk and the Battle of Britain receive similar brief texts and image panels, which are all centered on understanding the Canadian reaction to these events and the decision to engage internationally. From this point in the museum onwards, the

11 See Matthews (2013, 278-282) for the curatorial context of the car. Matthews reflects on the different possible reactions of visitors to the authenticity of the artifact through the frame of war trophies and notes that the "curatorial choices speak of the desire to evoke a particular historical narrative by inviting the projection of phantasy" (279), invoking the aura of Hitler, and through the trophy, the defeat of the Nazis by the Allies.

12 See also chapter 4.1.

13 The CWM does not give exact credits for many of its enlarged wall posters, so that the emotional effect of civilian suffering dominates. This is indicative of a certain style of museums, especially in the Anglophone world, that champions the emotional effect of images over documentation. Newer exhibitions from the last decade, however, usually indicate the source (see also Hawig 2019, 77-80). Another large difference between treating an image as a source vs. for emotionalization, that must be reflected on in all museums in this study, is whether photographs are used in varying sizes and/or enlarged to poster size. 
war becomes fully Canadian. Whereas the last rooms in the previous section on the First World War come close to giving the impression that Canada won the war on its own, the effect of the Second World War exhibition is slightly less nationally focused. This is due to the fact that many Canadian actions - as found in the weapon exhibits in the D-Day section - are presented as Allied actions with a Canadian focus. As a result of this Canadian focus, the war in the East is mentioned exactly once, in "The Air War" section on the panel "No. 6 Bomber Group (RCAF) and Its Targets," which states:

From 1943, most Canadian bomber squadrons in Britain were combined into the all-Canadian No. 6 Group of the RAF's Bomber Command. In conjunction with the Soviet Union's epic struggle in the East, the escalating air offensive in the West opened a 'second front' against Hitler's Germany, proving to many Allied civilians and military personnel that the war was being carried to the enemy.

The visitor learns nothing about "the Soviet Union's epic struggle in the East” or about the German policies of conducting a criminal war in the East. Consequently, the visitor is left to understand the expression 'dictatorships of evil' established at the beginning of the Second World War gallery. The museum's narrative assumes that the visitor already understands the justness of the war, allowing it to focus on a military, nation-based narrative of winning the war for the good of humanity.

Analyzing the CWM's “The Air War” section as well as the public debate surrounding its earlier depiction of Bomber command prior to the museum's opening, can help us understand how the museum's master narrative influences its ability to create experientiality for its visitors. To the right of the section's entry gate, the visitor finds two large info panels with four texts explaining the role of the Air War in the overall war effort, the objectives and successes of the Bomber Command, and the Canadian losses suffered. These panels highlight the disproportionally high Canadian contribution to Bomber Command; the reader cannot doubt that the bombing campaign was costly, effective, and successful, as reflected in the header of the main info panel: "Bombing to Win." Throughout, the section takes an aerial perspective. For example, next to a large screen playing footage of air bombings from above, there is a war painting entitled “Air Raid on San Guisto, Pisa,” painted by Flight Lieutenant Johann Alexander Goranson in 1947. Painted with mainly red, orange, and yellow, it illustrates a Canadian air raid on a German airfield in September 1943. The apocalyptic image is illustrated from the vantage point of a plane trailing behind those depicted in the painting. Theoretically, museum visitors could empathize with whoever is out of sight on the ground. However, since they have just read about the strategic necessity of the Air War for the destruction of German 


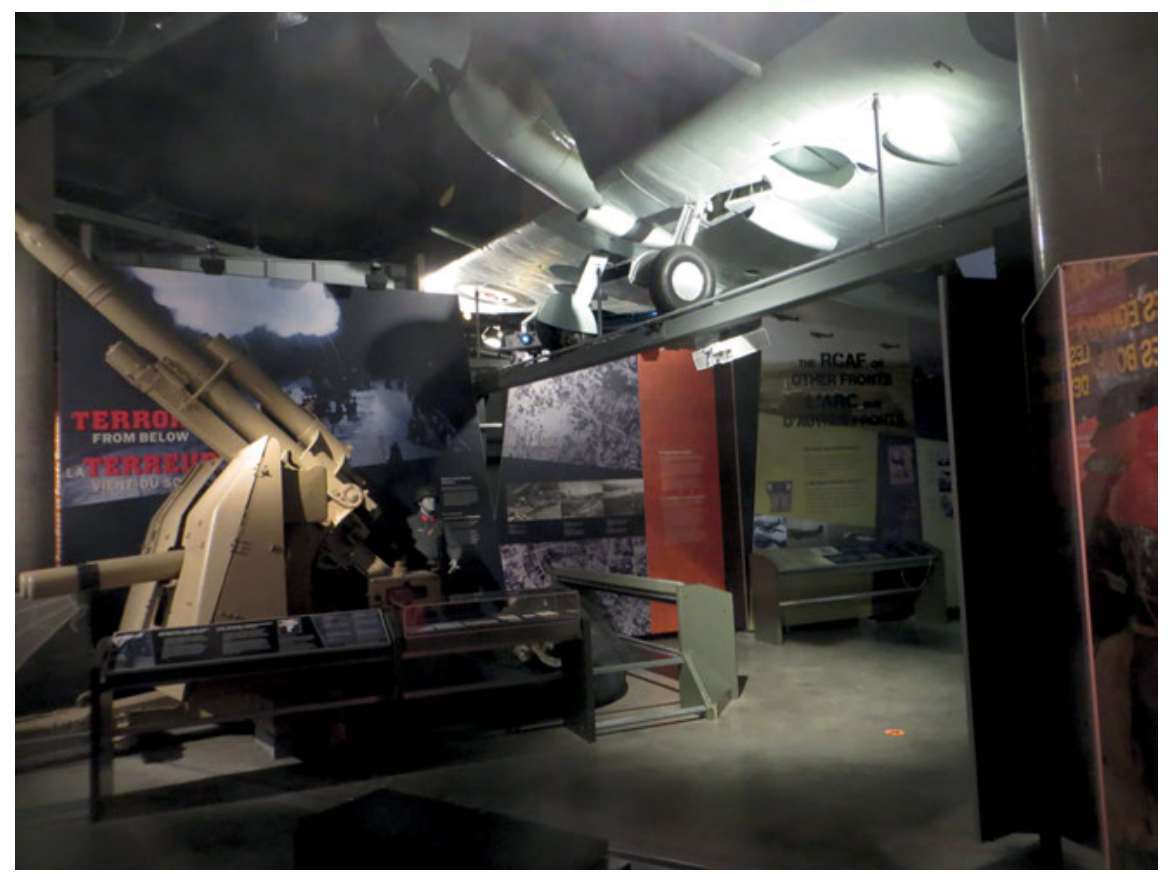

Fig. 5 "The Air War" section with subsections "Terror from Below" and "Bomber Command" in background, gallery “The Second World War: 1931-1945.” Permanent exhibition. Canadian War Museum, Ottawa (Photo: Author, 2015, courtesy of Canadian War Museum).

infrastructure, it seems much more likely that this painting will enhance the museum's narrative of the war as just and necessary. The interpretive possibilities this painting holds are diminished, as it is instead positioned to serve as evidence for the narrative argument made by the Second World War gallery.

Another example of how the "Air War" section steers the visitor to exclusively reflect on the Canadian perspective can be found toward the left of the entrance in the subsection "Terror from Below" (see fig. 5). This subsection focuses on how Canadian aircrews encountered German aircraft defense systems and is anchored by the artifact of a German anti-aircraft gun. Two enlarged posters of firing anti-aircraft gun batteries in front of a 188 millimeter flak anti-aircraft gun shape the atmosphere of the exhibit, supplemented by the mannequin of a German anti-aircraft gunner. Illustrated especially in the poster on the left, the flak produces orange clouds that indicate the intimidating and destructive effect it holds. In front of the flak is a damaged wheel of a Halifax bomber. The caption explicitly points out that this object serves as "testament to the effectiveness of German anti-aircraft defences." Showcases in front of the scene display letters 
discussing the deaths of Canadian airmen, medals commemorating their achievements, and, in particular, the case of George Chequer who died in a bombing attack on Berlin on January 30, 1944. The CWM displays Chequer's final letters to his parents, official documents informing his parents that their son was missing in action, and Chequer's service medals. The header of the subsection, "Terror from Below," subverts the traditional phrase used to describe aerial warfare as 'terror from above.' In this way, the museum creates the impression that the main threat in the Air War came from the defenders and not from the attackers on the offensive. There is of course no doubt that the life expectancy for bomber crews was considerably lower than in other service branches, resulting a high element of risk and fear - however, the CWM avoids any other perspective. Indeed, through the indirect effects it has on the visitor, the museum implies that the suffering and dangers faced by Canadian aircrews were at least comparable to the suffering of civilians on the ground.

A small wall display - about one third of the size of the two air defense posters - can be found on the left wall following the "Terror from Below" subsection (see fig. 5). This display deals with the Air War's effects on the ground. The original text of this panel created one of the biggest public controversies in Canadian museum history, resulting in the CWM eventually softening and lengthening the original text (Bothwell et al. 2008; Dean 2009). The visitor sees a large image of a destroyed German city, with three smaller photographs. The first depicts corpses of civilians; the second, a destroyed train station in Münster, citing the effect of collateral damage; and the third shows an image of Cologne in ruins in May 1942, relating to the first thousand-bomber attack in history. ${ }^{14}$ The extensively revised text of approximately 200 words describes the efficiency, development, purpose, and public support of the Allied strategic bombing campaign. Describing the end of the campaign's first half, the panel confidently states: "The attacks blunted Germany's economic and military potential, and drew scarce resources into air defense, damage repair, and the protection of critical industries." The second and final paragraph ends as follows: "Industrial output fell substantially, but not until late in the war. The effectiveness and the morality of bombing heavily-populated areas in war continue to be debated." Thus, the revised text allows the visitor a minor opening that brings up small doubts about the effectiveness of the early campaign and possibly triggers reflection on the strategic bombing of civilians in war. On the whole, however, the visitor is fully immersed in the Cana-

14 The photographs remain unchanged after the controversy. The CWM's tendency to make the whole Allied war effort, or even the whole war, centered on Canada, can be seen in the formulation of the caption: "an air-attack by more than 1,000 Canadian and Allied bombers." Of course the majority of bombers used in the attack were not Canadian. 
dian perspective, justifying the strategic effects of the Air War. Only one image displays civilian casualties - without any indication of specific historical context - making it so that the visitor cannot experience or understand the perspective from below. One of the most complex themes of the war is therefore simplified to fit within the structure of the national master narrative depicting heroic, sacrificial, and morally justified deeds necessary to save the world. This allows the CWM to tell a mostly unambiguous story of Canadian identity. Primary experientiality is reduced to a narrative argument and it is almost impossible to understand the Canadian war effort in relation to the war's larger picture.

Lastly, it is useful to consider the bomber campaign controversy (Bothwell et al. 2008; Dean 2009, 2013, 332-333) and look at the concrete changes the CWM had to enact in order to appease war veteran interest groups. The original text reads:

Mass bomber raids against Germany resulted in vast destruction and heavy loss of life. The value and morality of the strategic bomber offensive against Germany remains bitterly contested. The Bomber Command's aim was to crush civilian morale and force Germany to surrender by destroying its cities and industrial installations. Although Bomber Command and American attacks left 600,000 Germans dead, and more than five million homeless, the raids resulted in only small reductions in German war production until late in the war. (see Dean 2009, 4; Bothwell et al. 2008, 376-387)

As in the Japanese-Canadian relocation story discussed below, the original text panel diverged from the national master narrative and allowed for debate - to a certain extent - under the header "An Enduring Controversy." At the same time, even the original text read in isolation risks closing itself to interpretation due to the fact that it depicts the raids as a failure. Of course, if one considers the rest of the gallery, an implicit tension would have arisen, since the positive and necessary purpose of the campaign is described and alluded to in all other text panels and subsections. Furthermore, the original display included three quotations, which would have demonstrated openness and varying viewpoints that were later eliminated as a result of the controversy. The first one was by Air Officer Commander-in-Chief of the Bomber Command Arthur Harris, insisting upon the vital contribution of the campaign in bringing the war to an end; the second quotation was by the liberal public intellectual John Kenneth Galbraith, stating "that while the bombing campaign did not win the war, it helped the ground troops who did" (Dean 2009, 4); The third quotation was from the Canadian airman Flight Lieutenant W.E. Vaughan, who reflected on the consequences of his actions: "more than once I wondered 'how many people will those bombs kill?' However, you couldn't dwell on it. That's the way war is”' (Dean 2009, 4). 
What detailed historical critiques like the one from Robert Bothwell, Randall Hansen, and Margaret MacMillan (2008) do not take into account, is that the CWM could have employed war veterans' interpretations of their mission as an opportunity to diversify its narrative. The perspectives of veterans could have been added to the quotations already present, diversifying these voices without making moral judgments about historical truth. These quotations may not have contained confirmed historical knowledge, however, diverse perspectives are crucial in understanding how the Air War is part of Canadian cultural memory. If this had been done, the visitor - who is in no position to decide what the factual impact of the bombings really was - could have understood the dilemma of the controversy. Multiple perspectives within Canadian memory among the Canadian public, veterans, and scholars, would have allowed for the potential of primary experientiality, instead of the continued repetition of a single argument. This could have revealed why, from the perspective convinced of the moral prerogative of a just war, targeting civilians could have appeared to be a justified strategy. Additionally, it could have explained from the perspective of a Canadian member of Bomber Command why they carried out the same heroic, sacrificial job as anybody else in the Allied Forces. At the same time, the visitors would have still been able to see a moral issue that could be answered in various ways, and they might have been uncomfortable with the idea of strategic bombing, which would have been portrayed as at least factually controversial in terms of whether it was necessary and/or shortened the war. This would have also played an important role in helping visitors understand what the Second World War actually means for Canadians, both during the war and in its remembrance since then.

Museums mostly shy away from reflecting on public controversies surrounding their own exhibitions but in an altered display, the very root of the controversy could have been a successful topic for the exhibition. The CWM could have even created a more structural, secondary experientiality, since visitors would have had the opportunity to understand how cultural memory is constructed on a meta-level. However, if one integrates the remainder of the gallery, it becomes clear that its narrative emphasizes Canadian soldiers' hardship, sacrifice, and endurance in a just war (see also Dean 2009, 6). The overall style of the Second World War Gallery is clearly geared toward closure rather than openness. The CWM employs the technique of avoiding open voices that could be read outside of its master narrative, while still insisting on factual historiographical statements. This ironically led to public controversy in one of the few instances where they allowed for openness, or at least a perspective that diverged from the national master narrative. Shifting the display from historical truth and toward cultural memory and diverse perspectives would have opened the display to experientiality and might have avoided - or at least defused - the controversy. 
An enlarged handwritten poem entitled High Flight by pilot officer John Gillespie Magee Jr. at the end of the “Air War” section can serve as final example for the section's one-sidedness. It celebrates flying and its thrills as modeled on human dreams, and it could have come straight from the myth of Icarus: "Oh! I have slipped the surly bounds of earth / And danced the skies on laughter-silvered wings. / Sunward I've climbed [...]. Where never lark, or even eagle flew / And while with silent lifting mind, I've trod / The high untrespassed sanctity of space / Put out my hand and touched the face of God.” The museum's caption describes the success of the poem in capturing "the thrill and awe of flying." The American pilot serving in the RCAF (Royal Canadian Air Force) sent it to his parents several months before being killed in a flight accident. Ending the "Air War" section on this note corresponds to the heroic commemoration of individuals that is part of the "Terror from Below" subsection. It displays how the aerial warfare conquers nature, and the religious words at the end of the poem "sanctity" and the "face of God" - give the exhibit the feeling that the possible death of the pilot is linked to an almost holy mission. The CWM could have easily contrasted such a poem with a description how the Air War is perceived, namely its tension between the sublimity of the lights in the sky and fear and terror on the ground. Or if that was not possible because of the influence of veterans on public opinion, it could have at least added voices of Canadian airmen who knew about the effects of their mission and expressed doubts about the destruction they wrought on the ground. Even if the CWM remains solely focused on a Canadian collective perspective, ${ }^{15}$ it could have diversified the Canadian voices it uses. In doing so, it could have created experientiality, instead of merely purporting a prescribed narrative argument.

There are a few examples where the CWM diversifies its represented perspectives, often in regard to Canadian experiences that have been critically discussed from a contemporary human rights perspective. ${ }^{16}$ This can be seen in the museum's representation of Japanese-Canadian wartime internment. ${ }^{17}$ Under the

15 "The Canadian Experience" subsection is a good example for showing how the CWM overemphasizes the national angle. Except for the information that approximately $25 \%$ of all Canadians who died during the Second World War were from the Bomber Command, there is nothing Canadian in the Canadian experience. The risk of the bombing missions, of parachuting and being captured by the enemy would be exactly the same for a British or American crew-member. 16 Another example is the controversy about conscription and fighting overseas briefly indicated in the second section of the gallery. Though there is no evaluation of which position is superior, the opponents of conscription and military engagement overseas quickly disappear in the moral prerogative as narrated.

17 See also in detail Jaeger 2017b, 151-153. 
header "Forced Relocation," the visitor finds a two-dimensional poster and print exhibit that is divided into two columns. The visitor approaches the right hand side first. The main image is a photo of a truckload of people about to be relocated. The image is reminiscent of images of the transportation of cattle. Three newspaper title headers make clear that the demands for Japanese-Canadian internment come from different political parties, the government as a whole, and the people. The focus of the explanatory texts is racism and fear-mongering. A quotation by Japanese-Canadian Joy Kogawa reads: "The thousand little traumas of racism that were our little diet [sic]. Being despised. Being snubbed by white Canadians. Being portrayed in newspapers, as ugly, as unwanted, as deceitful, as somehow sub-human." The rest of the display presents five individual portraits, two of Japanese-Canadians in the Canadian military. This achieves an effect of contrast between the contributions of Japanese-Canadians to the war and to society and their ill treatment. Here the CWM diverts from its master narrative. It is the most open subsection in the Second World War gallery, since it allows the visitor to decide whether to compare the treatment of Japanese-Canadians to the Holocaust, or whether examples of Japanese-Canadian soldiers serving late in the war and the official Canadian apology in 1988 allow for reconciliation and closure. Because of this undecided tension allowing for secondary experientiality, the visitor can decide whether this is a historical case whose injustice has been overcome in the present, or whether Canadian society today continues to allow for similar injustices.

Unlike some of the objectives in the joint research strategy from 2013 (8) from the Canadian Museum of Civilization (in December 2013 renamed as Canadian Museum of History) and the CWM (Canadian Museum of Civilization and Canadian War Museum 2013), the focus of the current permanent exhibition is clearly restricted to military history and the Canadian perspective. The relevance of commemoration is not restricted to the three halls - the Hall of Honour, the Regeneration Hall, and the Memorial Hall - but impacts all exhibition galleries. Certainly, the museum's commemorative emphasis would enable it to present themes such as the Air War and the debate over the strategic bombing campaign in a hybrid format. Such a format could encapsulate both factual descriptions, such as how the Air War contributed to victory in the Second World War, and various questions and perceptions about these themes. Furthermore, if the exhibition were to be diversified at times with a more international gaze, it could supplement the visitor's understanding of specific Canadian perspectives. Theme $\mathrm{C}$ of the 2013 research strategy "Canada and the World" (14) has the potential to offer this opportunity if it creates instances of Canadian stories within the wider the world, instead of simply maintaining Canada's positive role in wars, 
conflicts, peace-keeping, and, consequently, a relatively undisputed cultural memory of the Second World War.

Through this research strategy, the two museums highlight the importance of commemorating the 150th anniversary of Confederation alongside the overlapping anniversaries of the First World War (100th) and the Second World War (75th). This actively acknowledges the connections between myth, memory, and the nation: "Using selected commemorations to explore concepts of myth, memory, and nation. These opportunities will focus attention on key events, explore diversity, and interpret difficult subjects" (Canadian Museum of Civilization and Canadian War Museum 2013, 8). The research strategy states goals such as documenting "the evolution of national identity since the 1940s" (Canadian Museum of Civilization and Canadian War Museum 2013, 9). On the one hand, this strategy focusing on commemorative issues furthers the CWM's objectives, which have in turn led to the dominance of an evolutionary national master narrative resulting in argumentative closure. This strategy emphasizes, for example, "Depicting the evolution of Canadian democracy" and "Documenting Canadian efforts in support of global security" (12) as two objectives of its theme C.1 "Compromise and Conflict: Power and Politics." These strategies allow for a more open and diverse approach, which becomes clear from the third objective in this category: "Exploring multiple concepts of political power, influence, and nationalism" (Canadian Museum of Civilization and Canadian War Museum 2013, 11). It is described as follows: "Debates over politics, power, community, and nationhood feature as prominently in Canada's past as in its present. The Museums will present multiple voices and unique perspectives on these, and encourage visitor and public engagement" (Canadian Museum of Civilization and Canadian War Museum 2013, 12).

The permanent exhibition of the CWM in general, and its Second World War gallery in particular, are synthesized to serve an evolutionary master narrative of an independent nation that streamlines almost all voices into a narrative argument. If the exhibition instead left room for multiple perspectives, debates, and questions, it could serve as an example for an open national narrative of war that allows visitors room to reflect and make their own interpretative decisions. In other words, it could have created a hybrid of primary experientiality (following simulated collective gazes) and secondary experientiality, so that visitors could approach historical interpretation from multiple angles. Another goal under C.2 "Compromise and Conflict: Population Movements and Settlements" is entitled "Exploring the impact of war and conflict on population movements" (13). The detailed description reads "War-affected refugees, the internally displaced, and post-war resettlement programs (e.g. Canadian and foreign veterans, war brides, and orphans).” Again, this could clearly diversify the museum's man- 
date, and even the 2005 exhibition diversifies itself in this direction at the very end of its fourth gallery. However, it remains to be seen how this can be implemented within a strongly Canadian perspective on the Second World War. The exhibit on Japanese-Canadian 'resettlement' is only a fraction of the current exhibition, which shows that the museum's exploration of population movements needs to integrate local perspectives from the European and Pacific theaters of war to a larger extent. Alternatively, the CWM could place more emphasis - similar to the "Examining the Holocaust" gallery in the Canadian Museum for Human Rights - on immigration and refugee movements to Canada (see also Maron and Curle 2018, 429-431), and the impact that Nazi Germany and the war had on these movements.

The new enlarged section "War at Home," opened in early 2015, focuses on the years 1917 and 1918 in Gallery 2. It indicates how the CWM intends to evolve from a military history museum, to a military history museum that encapsulates the stories of civilians in wartime, alongside aspects of general political and cultural history. ${ }^{18}$ For example, this section contains exhibits such as "Literature at the Home Front," "War and Music," "The Children's War," and "Families and War," among others. Its second room emphasizes the themes of conscription, including its societal impact leading to riots as well as a subsection on the right to vote and women's rights. The exhibition also highlights individual objects and stories that are not necessarily integrated as examples within a tight narrative, as often seen in the Second World War Gallery. This is exemplified in the exhibit "Shattered Love" on the newlyweds Sarah Robson and Ernest Percival Bartlett. Ernest died in combat in Europe in 1918. Among other objects, a gold pendant with Ernest's picture is displayed, which Sarah kept all her life. Visitors can decide whether they see the tragedy or deep feelings of love in the story. In this way, the display remains open as to whether the story expresses an attitude for or against wartime sacrifice. The texts on display here are more open than in the Second World War gallery: the visitor can interpret the information that voting rights were given to some - wives, daughters, mothers, and sisters of soldiers, while taken away from others - Canadians born in enemy countries. The computer installation "You be the judge," also allows the visitor to decide in four historical cases whether to accept or reject an exemption request from military service. ${ }^{19}$ Consequently, the section is a hybrid of primary and secondary ex-

18 I would like to thank the curator of the section, Mélanie Morin-Pelletier, for taking the time to explain its design to me on 27 May 2015.

19 This connects to the technique of debate wheels that is used in the fourth gallery of the permanent exhibition in which a question about the impact of societal developments is answered 
perientiality, allowing for a diverse re-experiencing of varied perspectives from the home front in the latter years of the First World War.

Whereas the CWM represents a closed narrative structure throughout its Second World War gallery, in the final parts of its fourth gallery - wherein the roles of the UN and NATO have become more controversial - the narrative opens up, enabling the visitor to ask questions. The second to last room is a roundel that introduces the post-Cold War period. Highly optimistic quotations by US President George H. Bush from September 11, 1990 and by UN Secretary General Kofi Annan from 1992 on the new free and peaceful world are juxtaposed; this is done through an installation of covers from international news magazines in English and French reporting on the endless on-going violence of war, conflict, and genocide around the world. The center installation "The Savage Wars of Peace" supplies a photo-montage of conflicts around the world (including 9/11), a helicopter from the Canadian Forces, and three video screens displaying footage from these conflicts. From here, the visitor enters the final room, which is made experiential through the presence of leading questions, such as "What is war?," "Who makes history?," "What do you fear?," "What will you do?," etc. Thus, contrary to the museum's narrative of Canadian national identity formation, the visitor is finally confronted with a (international or transnational) problem about warfare, which creates tension with the linear story of the majority of the exhibition namely which war provides hardship and suffering but is necessary for the greater good. Admittedly, the female child narrator in the Savage War film still seems to admonish the next generation to make the world safer, continuing the linear narrative toward peace (Rukszto 2008, 53). Nevertheless, the end of the exhibition sets up a tension that points to an open future. However, since this is not reconnected to the past, there is the overall expression of a linear model toward an open future, with the past and future remaining weirdly disjointed.

Both examples from the end of the permanent exhibition and the revised "War at Home" sections in the First World War gallery demonstrate that there are ways to open up Canadian history to allow for some interpretation and reflection by the visitor. However, the master narrative the museum puts forward in its representation of the Second World War - that the Canadian nation has grown out of war and conflict - indicates that the meaning of this war is stable and factual. The secure frame between good and evil only allows for a single interpretation, which heavily restricts this section's potential for experientiality. From the Canadian national perspective represented and exhibited in the museum, the

through six historical quotations. The visitor can decide how to deal with the proposed answers and standpoints. 
Second World War only seems to have one story: evil exists; the righteous can defeat evil through sacrifice and suffering; and the valor of the righteous wins out in the end.

\subsection{Warsaw Rising Museum}

As a hybrid of a historical museum aiming for historical objectivity and a memorial museum establishing and confirming a narrative of Canadian national identity that strongly depends on commemorative techniques, the format of the Canadian War Museum restricts its experientiality. In contrast, the Warsaw Rising Museum (WRM) is a memorial and narrative history museum (Majewski 2011, 151-152 $)^{20}$ utilizing strong experiential techniques. It employs close-ups of the historical events and emotionally engages the visitor (Heinemann 2011, 227). In doing so, it reaffirms the present worldview and a narrative of romantic martyrdom put forward by the Warsaw Uprising's position in Polish cultural memory (Szczepanski 2012; Kurz 2007; Żychlińska 2009; Korzeniewski 2016, 112-115) as historical truth. ${ }^{21}$ Monika Heinemann $(2011,235)$ notes how the museum operates with auditory, haptic, visual, and written language effects. Monika Żychlińska and Erica Fontana categorize the museum

as a ritual site where the interplay between authoritative knowledge, grounded in disciplinary expertise, and enchantment, carefully generated through architectural and aesthetic exhibitionary strategies, takes place. The political dimension of the WRM manifests itself in the power of refiguring traumatic past experiences and reshaping contemporary Polish collective identity, as intended by the museum's originators. (2016, 254)

The museum's strong memorial mission allows visitors to empathize with one specific ideological position and to identify with the historical collective of insurgents and, according to the museum's mandate, almost all Polish people. How-

20 It is also the first example of a new, modern museum style in Poland (Szczepanski 2012, 274; Bogumił et al. 2015, 68-69).

21 Here one can see the dynamic relationship between communicative and cultural memory. Whereas the WRM employs the voices of participants in the Uprising, its emotionalization techniques are geared toward the reinforcement of cultural memory that goes beyond the voices and interests of the survivors. Consequently, the WRM is strongly engaged in educating school classes on the 'true' memory, and engages in the advancement of the Uprising in popular culture, for example in the production of graphic novels, board games, and reenactment events (Stańczyk 2015, 750; 753-758). 
ever, it prevents an active primary experientiality in the form of experiencing empathy for the historical collective.

The WRM was more than twenty years in the planning and opened on July 31, 2004 - one day before the 60th anniversary of the beginning of the Uprising - by then-Warsaw Mayor Lech Kaczyński. ${ }^{22}$ It received a record number of 713,000 annual visitors in $2017^{23}$ It is located in the renovated building of a municipal tram power station in the Wola district where major events of and German atrocities during the Uprising took place. Its 3,000 square meter permanent exhibition is located on four floors (ground floor, mezzanine, first floor, and basement) and displays 800 exhibition items and approximately 1,500 photographs, and numerous films and sound recordings. ${ }^{24}$ Its focus is a close-up perspective of the sixty-three day Uprising (August 1 - October 2, 1944), framed by a brief section on the German occupation and the visit by Pope John Paul II in 1978 and his praise for the Uprising. The basement is used for the stand-alone exhibition "Germans in Warsaw" (see fig. 3) and a sewer replica as an experiential station for visitors. A large exhibition hall holding a replica of a B-24 Liberator plane, weapons used in the Uprising, a large film theater; a chapel on the side; a small twenty-four-seat theater featuring a 3D film showing the ruins of destroyed Warsaw in 1945; and a freedom and memorial park surrounding the building complete the ensemble.

As seen in the Canadian War Museum, the WRM develops a clear narrative message on how the Warsaw Uprising mirrors the development of Polish national identity. There has been considerable scholarly discussion on the permanent exhibition of the Warsaw Rising Museum. On the one hand, the museum has been seen as a model for a new narrative museum format that emotionally affects the visitor, following in the footsteps of, among others, the United States Holocaust Memorial Museum in Washington, DC and the House of Terror in Budapest. The WRM has also influenced later Polish history museums, particularly the Museum of the History of Polish Jews in Warsaw (2013-2014) and the Gdańsk Museum of the Second World War (Żychlińska and Fontana 2016, 246). On the other hand, the WRM has been criticized for its lack of historical contextualization that only allows for a positive reading of the Uprising, with tragic, religious, and heroic elements being employed to create a collective Polish perspective. The WRM is a memorial museum that morally and didactically codes

22 For a history of museum milestones between 2003 and 2011, see the museum guidebook (Muzeum Powstania Warszawskiego 2011a, 13-45).

23 See the interview by Poland In English with the Deputy Director of the Warsaw Rising Museum, Dr. Paweł Ukielski (Ukielski 2018).

24 See also the museum catalog, which gives a detailed insight into many of the artifacts displayed in the museum (Muzeum Powstania Warszawskiego 2011b). 
its narrative throughout its exhibition. Its webpage announces: "The Museum is a tribute of Warsaw's residents to those who fought and died for independent Poland and its free capital."25

As several researchers have pointed out, this is explicitly marked at the beginning of the exhibition. In the cloakroom, the entrance area, a stand-alone quotation by Jan Stanislaw Jankowski on a bronze plate welcomes the visitor: "We wanted to be free and owe this freedom to nobody." In the following vestibule, the visitor reads an approximately 150-word text under the headline "Memory and History," which highlights its false reception during Communism - before the visitor knows anything about the Uprising. The panel ends with the sentences: "The Home army commanders supposedly used the fighting against the Germans to pursue their own personal goals which conflicted with the goals of the Polish nation. Until the fall of Communism in 1989, the official propaganda portrayed the Warsaw Rising by contrasting the heroic struggle of the insurgents with their irresponsible and cynical commanders." A second panel on "Insurgents in the PRL" 26 describes how insurgents were "convicted in fake trials or even murdered by the communists." The panel describes a certain relief after the Thaw in 1956, yet ends with the decisive statement: "Only the independent Poland they were fighting for in the Warsaw Rising would pay homage to them - to those that lived to see it happen and to those that had died." These three texts frame the narrative of the whole permanent exhibition in three ways: First, the WRM's mission is above all commemorative: to "pay homage." Second, the exhibition functions historically under the assumption of a clear truth-value. The communists distorted and falsified the history of the Uprising, and only after Communism could the true version be told. Third, this true version is connected to the concept of the freedom and self-determination of the Polish nation. This links the Uprising to a linear, progressive narrative from occupation toward freedom. This reflects first the insurgents rebelling against German occupation and second, the new Polish independence won by overcoming the Soviet occupation. This framing effect produces a closed structure of meaning throughout the museum, as will be shown in a more detailed analysis below.

The WRM implies a chronological development of the exhibition, which is highlighted through calendar sheets on the wall indicating each day of the Uprising. Large maps of Warsaw chart the development of the Uprising's different phases. Sections that highlight specific phases of the fighting "W-Hour," "Fighting in August," "The Wola Massacre," "Fighting in September" lead visitors to

25 https://www.1944.pl/en, accessed 13 October 2019.

26 The Polish People's Republic, 1947-1989 (in Polish: Polska Rzeczpospolita Ludowa, PRL). 
experience simulated Polish and insurgent perspectives throughout the exhibition, in both the early parts examining Poland under German occupation and the different phases of the Uprising. In contrast to this, the exhibition also creates thematic sections such as "Food and Water," "Religious Life," "Everyday Life in the Rising," and "Field Post" to highlight specific aspects of the Uprising. It features twenty-three main sections on four floors and over fifty audio guide sections, making it at times confusing to navigate (see also Żychlińska and Fontana 2016, 260). Visitors are immersed in the fighting in a multisensory way through the exhibition's creation of an audioscape (see also de Jong 2018b, 93-98). They constantly encounter the sounds of fighting, original footage, and for example, the stroke of a clock for the W-hour, when the Uprising began. This makes listening to the audio-guide difficult at times, which prevents reflective distance. Instead, this immerses the visitor experientially in the scene of the Uprising where it is hard to gain a clear overview.

The museum first serves a commemorative purpose. Considerable prominence to the memory of those who participated in the Uprising is given throughout the museum, mainly through biographical survey texts, the telephone booths installation at the beginning of the section "The Rising after 60 Years," and audio clips of veterans' memories. The museum begins in the present, confirming the affirmative and nostalgic frame it places around the Uprising (Żychlinska and Fontana 2016, 254-257), which the visitor must accept according to the museum's master narrative. This is reaffirmed by the museum's central memorial installation, the monument of a wall-like cuboid full of bullet holes (see also Heinemann 2011, 228-229; Kurkowska-Budzan 2006, 138). The display panel explains that the monument is located "in the very "heart" of the museum, metaphorically alluding to the heart of those who fought, those who perished as well as those who survived: "It is a symbol to the Warsaw Rising and those who participated in it." The multimedia installation combines sounds from the fighting, radio reports, popular songs, and prayers running in 8-minute sequences. The visitor is invited to touch the monument and listen at each bullet hole, which allows for the reliving "of the atmosphere of those days." To further reinforce this recreation of the atmosphere of the past, the monument lists the days of the fighting. ${ }^{27}$

The way in which the Uprising's narrative is framed as a counter narrative to Soviet-Communist distortion and as commemorative nostalgia for recreating the past, shapes the whole exhibition. This fundamental meaning remains unalter-

27 Steffi de Jong reads the monument installation with Alison Landsberg as a form of bodily memory production that confuses the visitor through the conflation of the visitor's heartbeat with the heartbeat of historical participants in the Uprising (2018b, 195-197). 
able and unambiguous. Therefore, the museum can maintain a descriptive, documentary style throughout that gives the visitor an impression of a factual overview of numerous topics. This is exemplified in the section "Airdrops" on the top level of the museum: one panel, “Allied Airmen over Warsaw," highlights concrete facts and figures: "Allies make about 200 flights over Warsaw. Polish, British and South African crews take part in the airdrops. Only 525 out of 637 Poles return to their airbases in Italy." Throughout the museum facts, figures, concrete times, and locations are important in giving the visitor the impression that the majority of the exhibition is factual. In the subtext, the visitor finds allusions to heroics, which - through the focus on figures - seem to be factual as well: "133 are shot down. 7 of them [the airmen, SJ] manage to survive. They travel over 2.5 thousand kilometers. They have mostly German occupied areas under their wings." The following panel “Airdrops for Insurgents” highlights the concrete efforts and failure to reach the insurgents, similarly focusing on factual data, especially dates and the amount of supplies dropped in tons. In a factually descriptive tone, the responsibility for this failure is placed on Stalin: "Only 50 tons [out of 230 tons of Allied dropped supplies] fall into insurgents' hands. Until September 10, Stalin does not make Soviet airfields available to allied planes." The two subsequent sentences indicate a causal relationship. The visitor will, in all likelihood, simply attribute the failure to Stalin, rather than reflecting on the open question of whether the airdrops could have been more precise.

The overall section tries to show different sides of the airdrops by displaying enlarged poster-size photographs showing the joy they produce, alongside reflections on their failure. One photo-montage shows, among others, an image of an apparently misplaced container, with an image above it showing insurgents gathering the parachute with a container; and above, the insurgents apparently happily carrying the container with the new supplies (see fig. 6). The text accompanying this photo-montage reads: "The frontline in the fighting city is constantly changing and it is hard to spot it from the air. Every parachute reaching the streets controlled by the insurgents brings joy and it is easy to find volunteers to carry the airdrop containers." On the one hand, this factually documents failure and success. On the other hand, it plays upon the emotion of the success. Several quotations and objects on display support the positive impact of the drops as existentially necessary supplies and moral support. The Polish effort in these Allied deliveries is highlighted. There is no major criticism of the Americans, who made just a single attempt to fly over Warsaw; instead, the exhibition describes the American effort as “impressive - 107 'Flying Fortresses,' 1,100 airmen and 100 tons in containers." This connects to the panel "Stalin's Private Airfields," which describes that Soviet airfields were not made available, preventing the Americans from performing a large airdrop operation over Warsaw. The pan- 


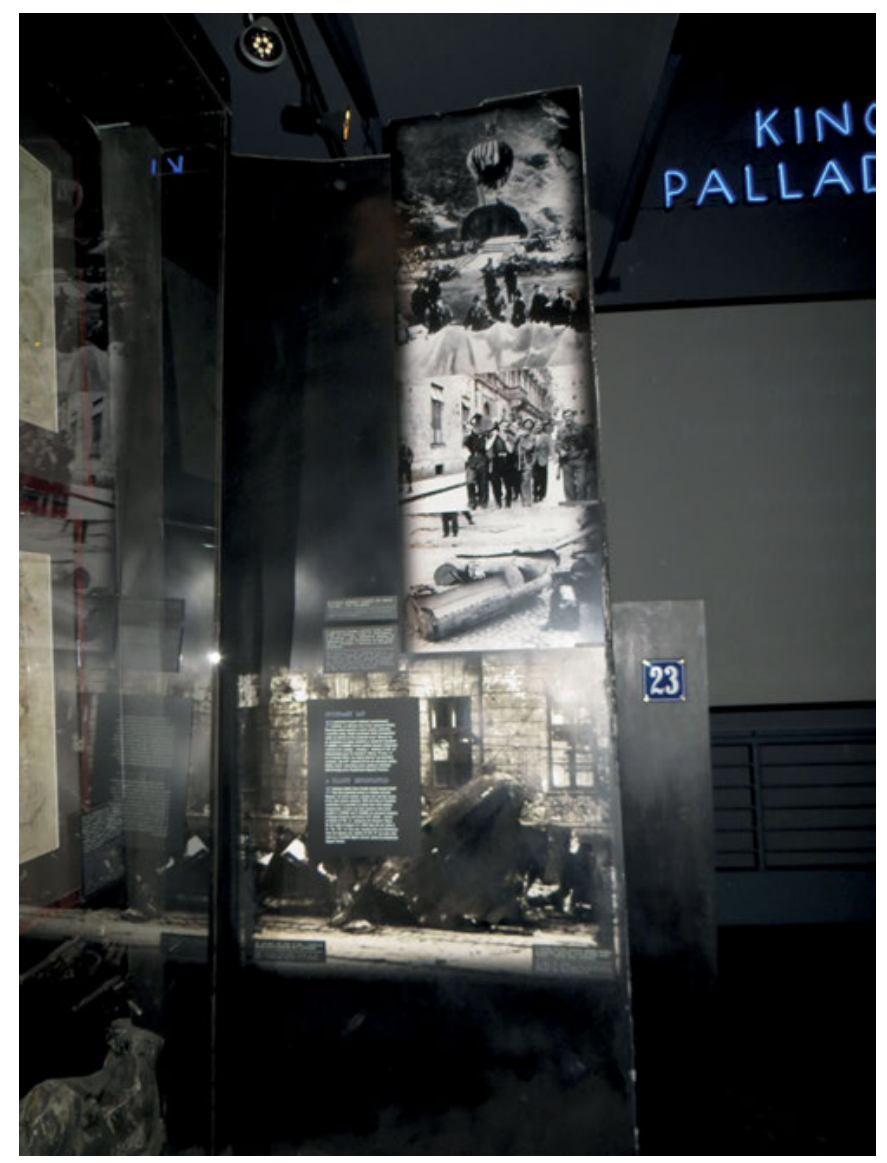

Fig. 6 Part of section “Airdrops.” Permanent exhibition. Muzeum Powstania Warszawskiego (Warsaw Rising Museum), Warsaw (Photo: Author, 2013, courtesy of Muzeum Powstania Warszawskiego).

el's text quotes the British pilot Stanley Johnson: "If only we could have landed there [on Soviet airfields], we could have taken an additional load ... I could never understand the Russians standing on the other side of Vistula River." The quotations blame the Soviets for denying the Allies use of their airfields and are then expanded toward the claim that the Soviets could have prevented the destruction of Warsaw - a crucial claim for the museum's narrative. ${ }^{28}$ That

28 See also Bömelburg et al. 2011, especially Król 2011 for the different perceptions and interpretations of the Uprising; see also Chu 2019, 130-131. 
the panel personally identifies Stalin several times as a historical agent reinforces the impression that a different outcome of the Uprising could have been easily achieved. Overall, the WRM's Air Drop section creates the impression that it exclusively presents factually unbiased information. One needs to think explicitly about curatorial strategies, in order to understand the ways in which the subtle techniques employed in this section reaffirm the museum's master narrative. This technique of creating a documentary, factual impression repeats itself throughout the whole museum, which makes it likely that the visitor will buy into the master narrative as well.

Many of the exhibition sections in the WRM have a thematic focus. This means they provide fairly factual information about a specific area of life during the Uprising. They often demonstrate how day-to-day life was organized during the fighting, indirectly supporting the part of the master narrative that suggests the Uprising led to freedom and independence. While demonstrating the functioning of civil and social life, the valor and tragic losses of the individuals participating in that life is simultaneously honored and commemorated. For example, the section "Field Post" features a combination of visuals and objects, including, a large display case mounted on the wall holding dozens of postcards, letters, an original mailbox, and a smaller display case with insurgent postage stamps. Individual biographies, accompanied by portrait photographs and approximately 100-120 word texts introduce the visitor to the Polish people who participated in the Uprising. Objects supplement these biographies, such as the shirt that Bolesław Jan Gepner 'Jasnotek' - a 13-year-old who worked as mailman of the Scout Field Post - wore when he was fatally shot. The more tragically stories about death ${ }^{29}$ are presented, the more they are portrayed as an almost religious sacrifice for the Polish cause. Other biographies highlight the skill-set and valor of the Field Post workers. The focus is on the everyday person and not on the leaders, reinforcing the message that all Poles were part of the Uprising. It is significant for the creation of a master narrative that these factual-commemorative narratives remain vague in regard to the Uprising's failures: at best, the insurgents encounter challenges. The visitor never hears whether the mail service connected to areas outside the districts held by insurgents. Nowhere does the exhibition reflect on civilians either inside or outside of the insurgent-held areas of Warsaw who might not have the supported the Uprising, nor does it reflect on the risks the Uprising held for the civilian population.

29 See also Heinemann 2011, 231, who notices the frequent use of gravestones, usually by lowerrank insurgents throughout the exhibition. 
The WRM enforces the message that starting the Uprising was the right decision in many indirect ways, including its representation of German perpetrators (see also Heinemann 2017, 78-90). They are mainly represented in the basement (see fig. 3), which physically separates the commemoration of Polish heroes from German crimes as well as the violence and cruelty of German atrocities. ${ }^{30}$ In this section, there are documentary texts, such as the biographies and fates of many German commanders and numerous facsimiles of German orders, among others. These are once again supplemented by a setting that steers the visitor's emotions in a specific direction - here, toward the implied genocide of the citizens of Warsaw. The oppressive atmosphere can make the visitor feel uncomfortable, who has hardly any room to analyze the presented material outside of the museum's good and evil framework. The Germans appear as one collective group, the Poles appear as another, and only Communist Poles are differentiated from all other Poles. The representation of Germans serves the exclusive purpose of providing evidence for the evil that the Uprising has the potential to defeat. To gain a better understanding of how this works, it is useful to look at a small side room in the permanent exhibition, located on the second floor in the final part of the exhibition and entitled "German Units." The room is void of any documentary information, except for the introductory text panel outside of the room describing the structure of the German forces and a chest of drawers with movable cases with biographical information on four German political and military leaders. The visitor enters a shrine-like squared room (Heinemann 2017, 82), with wall-sized, enlarged photographs on all sides. The four posters depict Hans Frank, Govenor of Generalgouvernement, residing in Wawel Castle with his wife and children; Wola insurgents who had to face veteran troops from the division Hermann Göring; a prison execution in Radogoszcz, near Łódź in 1942; and German soldiers on parade, honoring Hitler after capturing Warsaw in 1939. Furthermore, there are small objects throughout the room, such as an SS bronze cross with a sword that was pierced by an insurgent's bullet during the Uprising. The centerpiece of the room is a small table-like display case, containing the open diary of the 8-year-old Jerzy Arct, who experienced the Warsaw Uprising in the district of Sadyba and wandered through the destroyed city afterwards. None of the photographs on display in this room are related to

30 The stand-alone exhibition in the basement "Germans in Warsaw" was only opened on June 21, 2007 (Heinemann 2017, 79). For an analysis of this section see also Heinemann 2017, 84-90. Heinemann $(2017,89)$ notes some nuances that allow for a differentiated reading of the Germans, but also emphasizes that the section is dominated by a dehumanized, abstract depiction of the German enemy; for the depiction of the enemy in the WRM see also Bogumil et al. 2015, 141-143, who point out that human traits of the enemy are absent in the museum's depictions. 
the Warsaw Uprising. Instead, they showcase the normality of the perpetrators, the strong resistance against superior forces and war crimes, and reinforce the impression of the German soldiers' collective obedience and facelessness. The objects are all related to the Uprising and at least partially demonstrate the symbolic power of resistance. This display is fully emotive and holds the potential to manipulate the visitor into supporting the heroic deeds of the insurgents. The presence of the child's diary further supports this emotional message. The brutality of the Germans is pinpointed in the pictures of the Frank family and the Wola Massacre, since the visitor already knows about the family's criminality and the events of the Massacre. Thus, this room, which relies fully on affect, leads the visitor toward empathizing with the collective group of insurgents and all victims of the Germans. The strength of the WRM is that it often underlines its narrative message in an affective and emotional manner without overtly spelling it out. Therefore, it avoids explicitly moralizing good and evil, although its narrative is based on this dichotomy.

The exhibition's technique of appearing simultaneously factual and commemorative is also visible in the only section that clearly reports on a controversy or debate. On the one hand, the text on the panel "Views on the Rising" seems quite differentiated: "The Warsaw Rising stirs up extreme emotions, from more or less factual criticism to glorification.” An audio station provides eight positions from "decision-makers and participants in the Rising, historians and communist propagandists." In reality, there are the voices of two communists and six insurgents of different rank, so that besides the already rejected Communist view (see also Szczepanski 2012, 277), their opinions only differ regarding details, rather than their interpretations of the Uprising as such. Nevertheless, this station allows the visitor to think about the validity of different positions. However, the panel concludes by stating that the majority of insurgents are part of an emotional community: "Openly biased and unjust are opinions voiced by the Communists, such as Wanda Odolska, the leading propagandist of the Polish Radio. In the opinion of most insurgents the outbreak of the Rising was a necessity and they do not regret their decision to join in the fighting."

Further panels and objects completely undermine any possibility for openness in the audio station, as they continue in the clear black-and-white pattern established at the beginning of the exhibition. A panel entitled "Feud over the Rising" recreates the simple dichotomy of distorted memory under Communism versus free discussion after 1989: “After 1989 the Rising could be freely discussed also in Poland and continuous presence of this debate in the public life proves that the Poles are still tackling their history [sic]." The museum itself does not take an explicit position, as also seen in the implicit affective strategy it employs to represent the Germans. Nor does it encourage an open interpretation. Instead, 
the visitor who experiences the master narrative of the museum is led to be believe that the museum provides the possibility of free debate, after the Communist era of distortion of historical truth, and allows for a fair and differentiated position in the exhibition. Therefore, most visitors, as the success of the exhibition shows (Żychlińska and Fontana 2016, 262-263), will - in all likelihood draw the exact conclusions to which the WRM directs them. The factual tone throughout the WRM lures the visitor into feeling like debate is reflected in the exhibition. After all, the Uprising itself is marked as the road to Polish freedom, so that alternative interpretations of the Uprising seem unlikely for the visitor of this exhibition. Gaining freedom implies the possibility of stating the truth and establishing facts - in other words, closing a debate instead of leaving it open.

This is also evident in the remainder of the section, entitled "The Big Three." ${ }^{31}$ It emphasizes Stalin's propagandistic use of the Uprising ${ }^{32}$ and how the Big Three sacrificed Poland in their negotiations over the post-war distribution of power. This section also argues that the Allied Press failed to recognize the Uprising as a major contribution to the Allied cause: the tone of its texts clearly implies that the Uprising was a major contribution, which is confirmed through several quotations. For example, the diplomat George Kennan, deputy chief of the US mission in Moscow during the Warsaw Uprising, is quoted, presumably long after the Uprising and without any contextualization: "I wish that instead of mumbling words of official optimism we had had the judgment and the good taste to bow our heads in silence before the tragedy of a people who have been our allies, whom we have helped to save from our enemies and whom we cannot save from our friends.” The WRM uses quotations as Keenan's strategically; similarly, they integrate US President's Ronald Reagan's words at the 40th anniversary of the Warsaw Uprising: "It is right that we pay tribute to those who sacrificed all for independence and freedom.” The changes in Poland in the 1980s consequently allow for the collapse of the Communist myth, that the People's Army was the main insurgent force fighting the Germans. Thus, there is no doubt that the post-1989 era allowed for the recognition of the Warsaw Uprising and an open discussion about Polish identity. The WRM uses this to establish an implicit connection between the desire for freedom in the Warsaw Uprising and the freedom gained in 1989. Counterarguments against the Uprising there-

31 Referring to Winston Churchill, Harry S. Truman, and Joseph Stalin.

32 Stalin is the ultimate enemy and symbol of evil in the master narrative of the WRM, since he prevented the success of the Uprising and started the suppression of its 'true' narrative. 
fore hardly play a role; ${ }^{33}$ the amendment of Communist distortions is used as a platform to correct history and establish historical facts and truth. In the earlier section on the Polish Lublin government, the museum corrected the numbers of Communist People's Army soldiers and Home Army soldiers that participated in the Uprising to demonstrate "Communist 'facts."

The WRM's permanent exhibition does not have a strong temporal and progressive focus; it is instead built on the dichotomy between the Communists' distortion of truth and dishonoring of the insurgents on the one hand and freedom and factual truth as well as the commemoration of the insurgents' heroic and sacrificial deeds on the other. It simply connects the Uprising with independent Poland post-1989. Instead of futurity, the permanent exhibition's master narrative suggests a nostalgic reestablishment of the same Polish national freedom that was recognized by the insurgents during the Uprising. For example, the last section on the second floor and the end of the permanent exhibition talks about the Vatican and the Warsaw Uprising. It emphasizes two blessings given to the Uprising, the first of which was performed by Pope Pius XII on September 14, 1944, during the Uprising, who pointed out the Polish right to independence. This connects to a video and text panel highlighting how the first Polish Pope, John Paul II, lauded "the exceptional role of the Warsaw Rising in the history of Poland" during his first papal pilgrimage to Poland in June 1979. The last section of the audio guide concludes that the time has come to recognize the historical truth about the Uprising and foreshadows the universal freedom and 'correct' interpretation of the Uprising post-1989: "The time of truth was approaching. This was the time of the next generation." The museum is successful in producing "a sense of nostalgia and personal identification with the participants of the Rising” in its Polish visitors (Żychlińska and Fontana 2016, 262). Visitor analysis has shown the success of the WRM's use of technology (Żychlinska and Fontana 2016, 261). If the goal is to produce a specific historical truth based on cultural memory in the present, the WRM succeeds in doing just that as a memorial site: "a sense of continuity between past and present” (Żychlińska and Fontana 2016, 261) is established for many visitors.

The difference in temporality is also evident in comparison to the Canadian War Museum, in which the exhibition establishes its master narrative of a progressive development toward the Canadian nation and its positive role in the world. The WRM reinforces its master narrative by establishing a staged impres-

33 For example, the exhibition does not mention the controversy in Poland about whether the Uprising was really necessary and useful or whether it was a senseless sacrifice. It avoids any meta-reflection on how the memory or myth of the Warsaw Uprising's impact came into being (For details see Chu 2019, 133-135; Bömelburg et al. 2011, especially Król 2011). 
sion of factuality, while extensively fostering visitors' empathy with the insurgents and developing feelings of nostalgia for the past. The museum's skillful use of pseudo-factuality and emotion in its staging of memory as history stands in strong contrast to the argumentative-documentary style of the Canadian museum. Master narratives can be created in war and history museums through numerous techniques. Whether their contents are national, European, universal, heroic, or victim-oriented remains open. This can also be seen in the following chapter on the Imperial War Museum in London. There is no need to challenge other narratives, like in the WRM, or reinterpret existing cultural memory to allow a master narrative to emerge, as found in the Canadian War Museum.

\subsection{The Imperial War Museum in London}

The main branch of the Imperial War Museum in London (IWML) receives approximately one million visitors a year. ${ }^{34}$ It will not present a major Second World War exhibition before 2021, when both the Second World War and Holocaust Galleries are due to be completely redeveloped. ${ }^{35}$ Because of this, the discussion of the museum in this book is relatively short. ${ }^{36}$ The first phase of “Transforming IWM London," completed in 2014, focuses completely on the First World War and its centenary years. This has led to the opening of the new "First World War Galleries" (see also Jaeger 2017b, 169-172) and a redesigned atrium displaying seven exhibits of one or two objects, entitled "Witnesses of War." ${ }^{37}$ Its section "Turning Points 1934-1945," on the first gallery level surrounding the open atrium, presents different themes of the Second World War in

34 Imperial War Museum 2016-2017; the IWM's newer annual reports do not list individual visitor numbers per branch; overall the IWM and its five branches had an attendance of 2.688 million visitors in 2018-2019 (Imperial War Museum 2018-2019, 15).

35 See the IWM's website (https://www.iwm.org.uk/history/new-gallery-concepts-for-iwms-fu ture-revealed, accessed 13 October 2019). "The second phase of Transforming IWM London (TIWML) has continued with the developed designs being approved for the Second World War and Holocaust Galleries,” which will be probably delivered in 2021 (Imperial War Museum 2018-21; see also Imperial War Museum 2019-2024, 7-8, and Imperial War Museum 20182019, 11). The current stand-alone Holocaust Exhibition from 2000 will be briefly discussed in chapter 7 below.

36 For the history of the institution and its flagship museum in London (Lambeth), see Cundy 2015.

37 See chapter 8 below for a discussion of the display of the V1 bomb and V2 rockets as part of the exhibitions. Other 'witnesses' relating to the Second World War are a Supermarine Spitfire plane and a Soviet T34 tank. 
eight chapters using artifacts. This section seems like a stand-in to cover the war until the 2021 redevelopment is completed; it is too fragmentary to provide a full storyline and interpretation of the war, or to allow visitors to develop their own interpretations. ${ }^{38}$ Nevertheless, the IWML has always been an important model for restricted primary experientiality. ${ }^{39}$ Similarly to the Canadian War Museum, the IWML's official message describes its approach as an educational history museum, interested in creating a documentary and open "authentic historical experience" (Bardgett 1998, 32). ${ }^{40}$ Cundy $(2015,262-265)$ has shown how the IWM developed its educational function separately from a commemorative mission. However, this section demonstrates that the IWML still reinforces memory narratives as its primary effect.

One of the museum's objectives during its re-development in 1989-1990 was to immerse visitors in experiences that allow them both to have empathy with the past and to produce constructed yet suggestively real experiences of the past. In particular, this relates to the former Trench Experience (1990) concerning the First World War and the Blitz Experience (1989) concerning the Second World War. ${ }^{41}$ Since the first phase of "Transforming IWM London," both of these experiences are gone, much to the chagrin of many visitors - if one follows online blogs. ${ }^{42}$ The Blitz Experience contained a stage set with different scenes,

38 Its section "Bombers" is briefly discussed in chapter 8 below.

39 The Imperial War Museum's Churchill War Rooms (formerly Cabinet War Rooms) follows a similar concept. This branch is highly based on the authenticity of place, which is intentionally reconstructed through diorama scenes with mannequins and original objects. The IWM is working to make its exhibitions more interactive and includes voices of other people who worked together with Churchill in the Cabinet War Rooms (Imperial War Museum 2016-2017, 8). Yet it does not change its objective to simulate historical authenticity: "Walk in the footsteps of Churchill and glimpse what life would have been like during the tense days and nights of the Second World War. See where Churchill and his War Cabinet met and step back in time in the Map Room, which has remained exactly as it was left on the day the lights were switched off in 1945" (https://www.iwm.org.uk/events/cabinet-war-rooms, accessed 13 October 2019). The Churchill exhibition (Churchill Museum) itself is considerably more dynamic and the way that it simulates a secondary form of experientiality is worth analyzing.

40 This comment relates to the planning for the stand-alone Holocaust Exhibition in the IWML, but is indicative of the institution's general approach (see also Cundy 2015).

41 See also Noakes 2004; Schoder 2014, 73-74; Arnold-de Simine 2013, 33; Phillips 2003, 438. Lucy Noakes notes how the Blitz Experience "privileges notions of community togetherness and national unity over images of fear and destruction” (2004, 431).

42 There is still a trench experience, in the 2014 "First World War Galleries." The visitor walks into a large trench with a fairly soft sound installation of battle and airplane noises; the technical equipment of large objects looms over the trench. Yet the museum does not create a specific scene of attack (or the moments before it, as in the old trench exhibition). The visitor sees 
and the visitor had the opportunity to see the silhouette of London in flames, walk through the ruins of a street, and sit in an air-raid shelter. The experience affected all the senses through the shaking of the shelter, sound installations, simulated smoke, darkness, flashing lights, etc. This installation did not facilitate much learning and understanding; its objective was to come as close as possible to 'the real experience.' However, these reconstructions of a trench and an air-war shelter seem to have functioned as a playful trick to attract visitors via entertainment, rather than bringing them closer to experiencing the war and empathizing with historical people.

The Blitz Experience was, at least in part, replaced by the independent exhibition A Family in Wartime. This new exhibition was open from April 5, 2012 until January 2019, when it was closed so that the space could be re-developed for the museum's new Second World War galleries. The museum advertised $A$ Family in Wartime with the words: "Take a step back in time to the Second World War and experience life on the Home Front in London, through the eyes of the Allpress family. A Family in Wartime, IWM London's new major free family exhibition - will explore the lives of William and Alice Allpress and their ten children and what life in London was like during the war." 43 The Trench and Blitz experiences served to illustrate the different stages of two specific historical moments, immersing visitors in a trench attack, or in the experience of waiting out the bombing respectively. The visitor was "invited to relive a specific moment or milieu from the past” (Phillips 2003, 438), which functioned through engagement and proximity. In contrast, A Family in Wartime (Imperial War Museum 2017a, 34-35) allowed the visitor to observe and experience simultaneously. However, despite the potential it held for creating a reflexive understanding of the war through a variation of engagement and detachment, or proximity and distance, it ultimately continued to reinforce wartime myths.

The beginning of the exhibition was located in a narrow corridor with a large wall displaying photographs of the Allpress family, interspersed with three small monitors playing identical footage of the air-raids on London and their effects on the city. All photographs and portraits on display depicted a happy family with faces full of laughter. The introductory panel read: "This exhibition is about the Allpresses, a real family that lived in South London. As for so many others, the

photographs of soldiers, a devastated landscape, and the shadowy figures of soldiers moving along on the left wall of the trench. Thus, the visitor is never fully immersed and does not receive any information about what to do with this simulated trench. Its message seems to be the dominance and significance of new technologies that are explained in the following section.

43 IWM London press release February 2012. http://www.iwm.org.uk/sites/default/files/pressrelease/A_Family_in_Wartime_0.pdf (accessed 13 October 2019). 
war changed their lives forever." An enlarged quotation by Eva Allpress, one of the ten children, on the right wall stated: "We were a family that were really close together." In the back of the entrance corridor, the visitor walked toward one poster featuring an enlarged photo of a street with several houses completely reduced to rubble. None of the photographs had a caption or source. Whereas the exhibition never overwhelmed visitors into pretending they were close to real past experiences, it immediately steered them emotionally. The quotation, the many portraits, and the text, suggested a perfect and orderly world that was threatened and then destroyed by the war. Since the Allpresses were pitched as a model of "so many others," the visitor could draw connections to this exemplary everyday experience. On the right hand side of the entrance corridor, the visitor found an Anderson shelter, which they could see either at the beginning or very end of the mostly circular exhibition. The presence of this shelter helped the visitor understand the war's threat to the Allpresses' world. The shelter was large enough to climb into, and once inside, one could hear an audio clip of Betty Allpress speaking about her experiences during the Blitz. A photograph of a destroyed Anderson shelter lying in rubble acted as a backdrop to the physical shelter. This further enhanced the feelings of threat, destruction, and the intrusion of the war into everyday life, created by the exhibition. The surrounding walls at the end of the exhibition showed bombed-out houses and numerous bombshells, intensifying this impression.

In the section following the entrance corridor, the visitor came across a model and digital projection of each room of the Allpresses house in Lambeth (i.e. in fairly close proximity to today's site of the Imperial War Museum). It was here that they were introduced to mini biographies of the family's two parents and ten children. Two of the sons served in the war; three of the daughters performed fire watch duties and worked in the Women's Voluntary Service; and the remaining daughters took on maternal or household roles, meaning they did not have to work directly for the war effort. The museum clearly avoided making the story of any family member particularly heroic - they instead served as examples of the ordinary British citizen, mostly on the home front. The visitor was then presented with period-appropriate interior rooms, a living room and a kitchen, and display cases holding everyday objects sorted by topics such as evacuation, rationing, the Blitz, the Women's Voluntary Service, or the Southern railway (where the father had worked in a skilled job as an engine driver that exempted him from conscription).

The object display cases were often accompanied by the voices of the Allpress children reminiscing about this time. This was exemplified in the section on clothes rationing "Make Do and Mend" (see fig. 7). The section notes that Eva worked at a local draper's shop, which sold fabric and dressmaking material. 


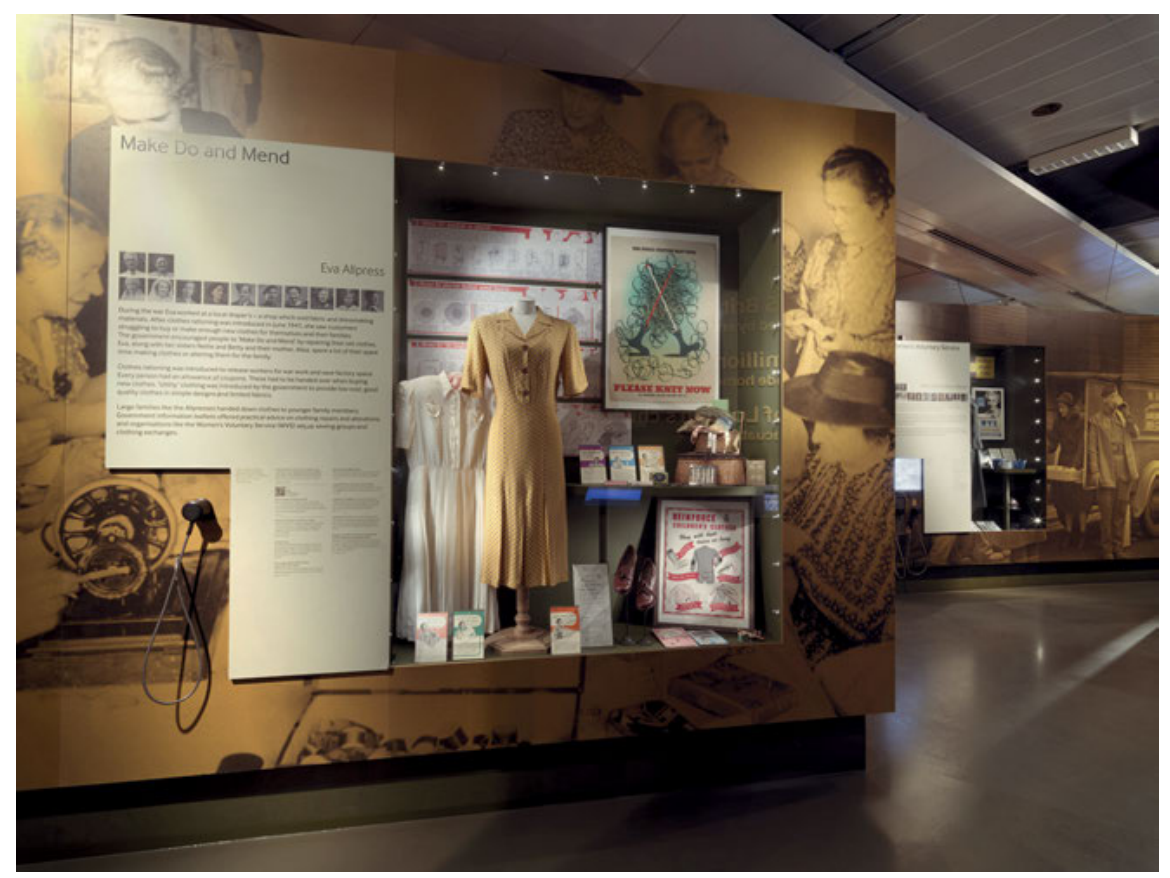

Fig. 7 "Make Do and Mend" cabinet. Family in Wartime exhibition. Imperial War Museum, London (Photo and (C) Imperial War Museum).

The display case contained a few dresses and pairs of shoes, but it mainly presented posters such as "Please Knit Now" as well as title pages and illustrations from do-it-yourself manuals. The whole section served an illustrative function for the duty and everyday life of British citizens on the home front; the Allpresses made-do and did a lot of mending. In the middle of the exhibition, there was a quotation by Nellie: "we were all so anxious to stay alive that we just sort of carried on," indicating the sober mood of everybody living through the war. Similarly, two quotations from after the war read: "The war had finished, you just couldn't believe it" (Betty) and "We were lucky enough that we had all our brothers coming back" (Eva). These quotations demonstrated the personal relief and joy felt by most at the end of the war, in stark contrast to the photographs of the destroyed Anderson shelter.

The Family in Wartime exhibition was clearly aimed at bringing the visitor a surface-level experience of the war; in doing so, it did not fully allow for an internalization or understanding of the Blitz as a historical experience. The exhibition greatly reduced the complexity of history and gave the visitor the impression that all civilians had an almost identical fate. On a primary emotional level, 
it was easy to identify with John's frustrations over being evacuated. However, this did not make reference to possible variations on his experience, or help one gain an understanding of the bombings' larger repercussions. How did the Blitz influence lives afterwards? What were some of the wartime traumas suffered by civilians? Instead, the IWML closed with facts and figures charting the impact of the Blitz and hopeful quotations from the Allpress children. Thus, the exhibition was seemingly successful in connecting with older generations who recognized elements of their former houses and lives in those of the archetypical Allpress family. It also succeeded in enticing younger generations and children by allowing them to connect with basic human needs and emotions such as food, clothes, housing, and the importance of family. It is telling that the Allpresses were depicted as so ordinary; in doing so, hardly anything unique about their personal story was expressed. The exhibition balanced an emotionalizing experience with the commemoration of a generation through the simulation of a possible everyday experience. It lacked both the ability to raise questions and the means for distantiation. The visitor was always so close to the war experience that its emotional impact dominated without eliciting any kind of analysis. The visitor received the strong impression that this was the real collective experience of the British people during the Blitz.

Therefore, the IWML - even without their original Blitz Experience - still put forward a restricted primary experience of the past. This restricted primary experience contributed to myth building regarding both the place of the Blitz and the every-day life of the typical British family in wartime in British collective memory today. The 2012 exhibition was certainly marked by a change in tone. It was neither heroic nor sensational; it contributed to the visitor's emotional experience in more subtle ways - as seen in the analysis of its opening corridor. ${ }^{44}$ However, because of its reconstructive approach, the visitor could only confirm the exhibition curators' meaning making and storytelling. It both fed into an existing collective imagination and confirmed the predominant communicative and cultural memory, which in turn reinforced the mythical status of British wartime resistance. Here, memory clearly dominated history, without allowing the visitor to take an active role in this process. In this way, the exhibition's potential for experientiality was restricted.

44 Without a more comprehensive historical exhibition of the war it is impossible to understand how the IWML is aiming to interpret the Second World War in the second decade of the twentyfirst century and beyond. 